\title{
Image-guided pancreatic biopsy; can we trust it as a diagnostic alternative?
}

\author{
Thiago Queroz ${ }^{1}$, Wanderley Marques Bernardo² Marcos Roberto de Menezes $^{3}$ \\ ${ }^{1} \mathrm{MD}$, Radiologist, Hospital Sírio-Libanês, São Paulo, SP, Brazil \\ 2Programa Diretrizes, Brazilian Medical Association \\ ${ }^{3} \mathrm{MD}$, Coordinator of the Centro de Intervenção Guiada por Imagem, Hospital Sírio-Libanês, São Paulo, SP, Brazil
}

\section{INTRODUCTION}

Most pancreatic adenocarcinomas are unresectable at the time of diagnosis, ${ }^{1}$ or present image limitations in the case of non-adenocarcinomas, ${ }^{2}$ thus posing a challenge for adequate histological sampling without the aid of laparoscopy. The American Joint Committee on Cancer considers the endoscopic ultrasound-guided diagnostic puncture as a procedure of choice. ${ }^{3}$ In recent years, with advances in imaging methods, computed tomography (CT) and percutaneous ultrasound have become a diagnostic alternative in case of failure diagnosis, with the possibility of collecting histological fragments. ${ }^{4-8}$

\section{Method}

Retrospective cohort analysis of hospital records of patients undergoing ultrasound-guided percutaneous biopsy and/or CT scan based on positive or negative histological findings in patients undergoing the percutaneous technique as first alternative or after failure of an endoscopic technique. We used the same pathology laboratories for the analysis of our histological fragments.

\section{RESULTS}

Fifty-five image-guided percutaneous biopsies were included, 11 of which had undergone prior endoscopic attempt with negative results. The average age was 62 years; 25 patients were male and 30 female. The mean size of the lesion was $4.75 \mathrm{~cm}$, with $55 \%$ in the head and $45 \%$ in the body/tail of the pancreas. Positive results were possible in $85 \%$ of the cases, with 36 adenocarcinomas; three B-cell lymphomas and four metastases (two gastrointestinal tract, one renal, one pulmonary); one epithelial microcystic lesion; two neuroendocrine tumors; and one chronic pancreatitis. Of the 11 cases of prior negative biopsy by endoscopy, we were able to reach a diagnosis in $72 \%$, with seven adenocarcinomas and one epithelial microcystic lesion. All results were obtained with only a minor complication characterized by a self-limited perihepatic hematoma. There was no tumor dissemination in the puncture needle path (Table 1).

\section{Conclusion}

In cases of negative endoscopic biopsies of pancreatic lesions, the ultrasound-guided percutaneous and/or CT method can be an effective and safe alternative for histological diagnosis.

Keywords: cancer, biopsy, CT-guided biopsy, pancreatic tumor.

TABLE 1 Positive results of image-guided percutaneous biopsies of pancreatic lesions.

\begin{tabular}{ll} 
Results & Number of patients \\
\hline Adenocarcinoma & 36 \\
\hline Lymphoma & 3 \\
\hline Metastasis* & 4 \\
\hline Epithelial microcystic lesion & 1 \\
\hline Neuroendocrine & 2 \\
\hline Chronic pancreatitis & 1 \\
\hline Total & 47 \\
\hline
\end{tabular}

*Two gastrointestinal tract; one renal; and one small cell lung carcinoma. 


\section{References}

1. Goldin SB, Bradner MW, Zervos EE, Rosemurgy 2nd AS. Assessment of pancreatic neoplasms: review of biopsy techniques. J Gastrointest Surg. 2007; 11(6):783-90

2. Bellizzi AM, Frankel WL. Pancreatic pathology: a practical review. Lab Med. 2009; 40(7):417-26

3. Exocrine pancreas. Greene FL, Page DL, Fleming ID, Fritz AG, Balch CM, Haller DG, Morrow M, editors. American Joint Committee Cancer Staging Manual. 6. ed. New York: Springer; 2002. p. 157-64.

4. Werner B, Campos AC, Nadji M, Torres LFB. Uso prático da imunohistoquímica em patologia cirúrgica. J Bras Patol Med Lab. 2005; 41(5): 353-64.
5. Paulsen SD, Nghiem HV, Negussie E, Higgins EJ, Caoili EM, Francis IR. Evaluation of imaging-guided core biopsy of pancreatic masses. AJR Am J Roentgenol. 2006; 187(3):769-72.

6. Amin Z, Theis B, Russell RC, House C, Novelli M, Lees WR. Diagnosing pancreatic cancer: the role of percutaneous biopsy and CT. Clinradiol. 2006; 61(12):996-1002.

7. Horwhat JD, Paulson EK, McGrath K, Branch MS, Baillie J, Tyler D, et al. A randomized comparison of EUS-guided FNA versus CT or US-guided FNA for the evaluation of pancreatic mass lesions. Gastrointest Endosc. 2006; 63(7):966-75

8. Herrnandez LV, Bhutani MS, Eisner M, Guda NM, Lu N, Geenen JE, Catalano MF. Non-surgical tissue biopsy among patients with advanced pancreatic cancer: effect on survival. Pancreas. 2009; 38(3):289-92. 